\section{Impact of Indole-3-Butyric Acid on Adventitious Root Development from Cuttings of Tea}

\author{
Simone da Costa Mello ${ }^{1}$, Jéssika Angelotti-Mendonça ${ }^{1}$, \\ Lucas Baiochi Riboldi ${ }^{1,3}$, Luigi Tancredi Campo Dall'Orto ${ }^{1}$, \\ and Eduardo Suguino ${ }^{2}$
}

\begin{abstract}
ADDITIONAL INDEX WORDs. propagation, Camellia sinensis
SUMMARY. The objective of this study was to investigate the effects of the application of indole-3-butyric acid (IBA) at concentrations of $0,30,60$, and $90 \mathrm{mg} \cdot \mathrm{L}^{-1}$, for 24 hours, on rooting of softwood and semihardwood cuttings of tea (Camellia sinensis var. sinensis 'Yabukita' and C. sinensis var. assamica 'IAC-259') collected in winter and summer. In the summer, IBA increased root percentage of softwood cuttings from 'Yabukita' compared with the control. However, the rooting of semihardwood cuttings was unaffected by this growth regulator. In winter, application of $90 \mathrm{mg} \cdot \mathrm{L}^{-1}$ IBA increased the rooting regardless of the type of 'Yabukita' cuttings. In addition, in 'IAC-259', there was an increase in dry weight, number of roots (NOR), and rooting percentage of softwood cuttings collected in summer with application of $90 \mathrm{mg} \cdot \mathrm{L}^{-1}$ IBA compared with control. In contrast, during the same period of the year, the semihardwood cuttings of 'IAC-259' were unaffected by the IBA. In winter, the percentage of cutting survival, rooting, the number, and length of roots were unaffected by IBA in 'IAC-259'. Overall, we would recommend the use of exogenous IBA for rooting of cuttings collected in the summer or winter.
\end{abstract}

$\mathrm{T}$ he most important producers of tea are China, India, and tropical southern Asia. In Brazil, this plant is cultivated in Vale do Ribeira region, São Paulo state, to produce mainly black tea.

The success of tea productions depends on a uniform stand of plants that are propagated by cuttings, because sexual propagation cannot guarantee high yield and quality. However, tea plants are considered a difficult-to-root species (Wei et al., 2013). The difficulty of rooting can be caused by external factors, such as light and temperature, and internal factors, such as nutrition, age, and plant hormonal balance (Hartmann et al., 2011). Furthermore, the physiological age of the plant material affects the promotion of adventitious roots in some species. According to Gomes et al. (2002), guava plants (Psidium guajava) have increased rooting in softwood cuttings, whereas in litchi (Litchi chinensis), optimal rooting was in semihardwood cuttings

${ }^{1}$ Department of Crop Science, Universidade de São Paulo, Escola Superior de Agricultura Luiz de Queiroz, Pádua Dias Ave., 11, P.O. Box 09, Piracicaba, Brazil 13418-900

${ }^{2}$ Agência Paulista de Tecnologia dos Agronegócios, Apta Regional, Lafaiete St., 1904, Ribeirão Preto, Brazil 14015-080

${ }^{3}$ Corresponding author. E-mail: scmello@usp.br.

doi: 10.21273/HORTTECH03378-16
(Carvalho et al., 2005). The impact of physiological age of tea on rooting capacity has not been reported.

Auxins as promoters of the development of adventitious roots on stems are widely known. Many woody species have early preformed adventitious root primordia on their stems, which remain dormant, unless they receive auxin stimulus (Salisbury and Ross, 1992). IBA is among the exogenous auxins applied for rooting of cuttings because it presents greater resistance to photodegradation, inactivation by biological action, and adherence to the cutting (Hartmann et al., 2011). However, the beneficial effects of exogenous auxins are concentration dependent. The application of auxin promotes rooting growth when used in a certain concentration; the effect becomes inhibitory when concentrations are higher. The ideal concentration for the treatment of cuttings varies according to the species and varieties (Zietemann and Roberto, 2007).
The use of this growth regulator has been promising in the rooting of cuttings of several species such as peach [Prunus persica (Mindêllo Neto, 2005)], guava [Psidium guajava (da Costa et al., 2003)], and vanilla [Vanilla planifolia (Silva et al., 2009)].

In Brazil, few studies have been performed on the effects of cutting age, growth regulator application, and collection season of cuttings for tea propagation. The objectives of this study were to evaluate the rooting of softwood and semihardwood cuttings in two botanical varieties of tea under different concentrations of IBA.

\section{Materials and methods}

EXPERIMENTAL SITE. The experiments were conducted in a greenhouse located in the experimental area of the Department of Crop Science, belonging to Escola Superior de Agricultura "Luiz de Queiroz," State University of São Paulo, Piracicaba, Brazil (lat. $22^{\circ} 42^{\prime} 30^{\prime \prime} \mathrm{S}$, long. $\left.47^{\circ} 38^{\prime} 00^{\prime \prime} \mathrm{W}\right)$. Intermittent fog system maintained the relative humidity around $70 \%$. The relative humidity was controlled automatically by sensors that were connected to a datalogger (CRI0x; Campbell Scientific, Logan, UT), which continuously recorded relative humidity (HMP35 probe; Campbell Scientific). The average temperatures were 24.3 and $18.50{ }^{\circ} \mathrm{C}$ in summer and winter, respectively, and light levels were 9.96 and $7.79 \mathrm{MJ} \cdot \mathrm{m}^{-2} \cdot \mathrm{d}^{-1}$ for these seasons.

EXPERIMENTAL DESIGN. 'IAC259' and 'Yabukita' were taken from mother plants located in São Miguel Arcanjo, Brazil. Collection of plant material was performed in Jan. 2010 (summer) and June 2010 (winter) from 15-year-old mother plants, pruned 2 months before the collection. Softwood and semihardwood cuttings were collected and divided into three parts: basal, middle, and apical. Each 5 to $7 \mathrm{~cm}$ cutting

\begin{tabular}{llll}
\hline $\begin{array}{l}\text { Units } \\
\text { To convert U.S. to SI, } \\
\text { multiply by }\end{array}$ & U.S. unit & SI unit & $\begin{array}{l}\text { To convert SI to U.S., } \\
\text { multiply by }\end{array}$ \\
\hline 2.54 & inch $(\mathrm{es})$ & $\mathrm{cm}$ & 0.3937 \\
38.7501 & $\mathrm{~kW}-\mathrm{h} / \mathrm{ft}^{2}$ & $\mathrm{MJ} \cdot \mathrm{m}^{-2}$ & 0.0258 \\
28,350 & $\mathrm{oz}$ & $\mathrm{mg}$ & $3.5274 \times 10^{-5}$ \\
1 & $\mathrm{ppm}$ & $\mathrm{mg} \cdot \mathrm{L}^{-1}$ & 1 \\
$\left({ }^{\circ} \mathrm{F}-32\right) \div 1.8$ & ${ }^{\circ} \mathrm{F}$ & ${ }^{\circ} \mathrm{C}$ & $\left({ }^{\circ} \mathrm{C} \times 1.8\right)+32$
\end{tabular}


Table 1. Effect of indole-3-butyric acid (IBA) concentration $\left(0,30,60\right.$, and $\left.90 \mathrm{mg} \cdot \mathrm{L}^{-1}\right)$ and cuttings type (softwood and semihardwood) on cutting survival (CS), rooting, number of roots (NOR), dry weight of roots (DWR), and root length (RL) of 'Yabukita' tea under greenhouse and commercial substrate conditions, during the summer (Jan. to Feb. 2010) and winter (June to Aug. 2010) at Piracicaba, Brazil.

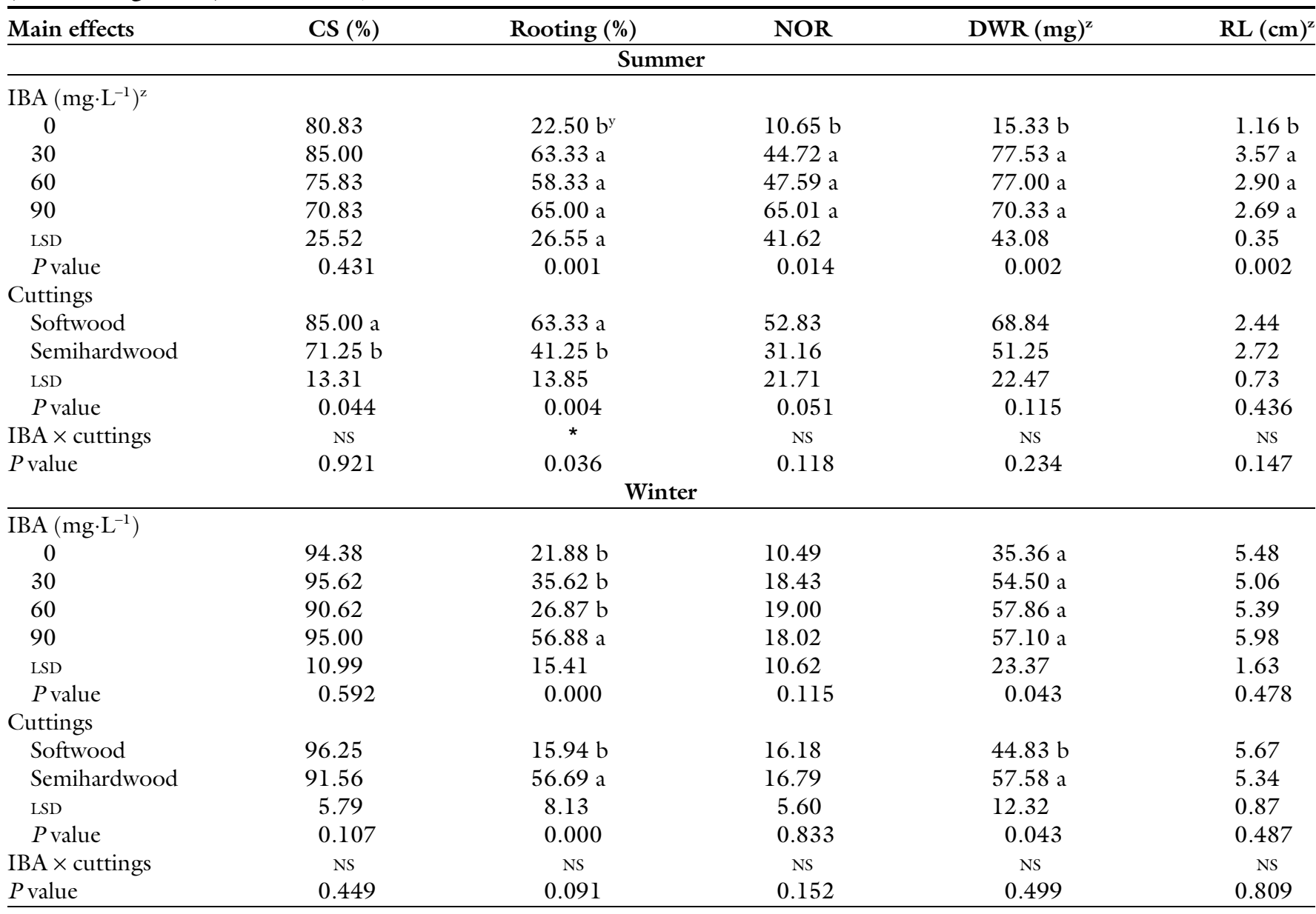

LSD = least significant difference.

${ }^{\mathrm{z}} \mathrm{l} \mathrm{mg}=3.5274 \times 10^{-5} \mathrm{oz} ; \mathrm{l} \mathrm{cm}=0.3937$ inch; $1 \mathrm{mg} \cdot \mathrm{L}^{-1}=1 \mathrm{ppm}$.

${ }^{y}$ Means within columns followed by different letters differ significantly at $P \leq 0.05$ by Tukey's multiple range test.

*Significant at $P \leq 0.05,=$ not significant.

contained a bud and an entire leaf at the distal end. The cuttings were put into the experiments $3 \mathrm{~h}$ after collecting the plant material from collection in São Miguel Arcanjo city.

The experimental design was a randomized block with four replications, with a $2 \times 4$ factorial treatment design, of two types of cuttings (softwood and semihardwood) and four concentrations of $\operatorname{IBA}\left(0,30,60\right.$, and $\left.90 \mathrm{mg} \cdot \mathrm{L}^{-1}\right)$, for $24 \mathrm{~h}$. The cuttings were placed in 72 -cell polystyrene trays containing a vermiculite medium. The cuttings were placed in the fog system for 45 $\mathrm{d}$ in the summer and $60 \mathrm{~d}$ in the winter. There were 20 cuttings in each plot. Two experiments-one in summer and the other in winter-were conducted with 'IAC 259' and 'Yabukita'.

Rooting meAsurements. The rooting characteristics were evaluated in both experiments were number of roots, root length (RL), and dry weight of roots per plot (DWR), percent rooted cuttings per plot (PR), and cuttings survival [CS (percent)].

STATISTICAL anALYsis. Statistical analysis of data was performed for each variety and season, separately, using SAS (version 9.2; SAS Institute, Cary, NC). The results were analyzed by analysis of variance (ANOVA) and Tukey's test at $P=0.05$. The percentage of rooting and CS were transformed by $(x+0.5)^{0.5}$, because the distribution of the data did not accord to the basic requirements necessary to do ANOVA.

\section{Results and discussion}

IBA EFFeCts ON CUTTINGS ROOTING. For cuttings of 'Yabukita' collected in summer rooting percentage,
NOR, DWR, and RL were greater with IBA compared with control (Table 1). 'Yabukita' CS was unaffected by the application of IBA (Table 1).

In the winter, CS, NOR, DWR, and RL were unaffected by IBA treatments for 'Yabukita'. PR was higher in treatments with $90 \mathrm{mg} \cdot \mathrm{L}^{-1} \mathrm{IBA}$ than other rates of this growth regulator and control (Table 1 ).

In 'IAC-259' in summer, RL, DWR, NOR, and PR increased with the application of $90 \mathrm{mg} \cdot \mathrm{L}^{-1} \mathrm{IBA}$ compared with control and was statistically similar to the other IBA concentrations. In the winter, only DWR of 'IAC-259' cuttings was affected by the application of IBA, with highest concentration increasing DWR by $88 \%$ compared with the control.

The fact that rooting of 'IAC259' was unaffected by the application 
Table 2. Effect of indole-3-butyric acid (IBA) concentration $\left(0,30,60\right.$, and $\left.90 \mathrm{mg} \cdot \mathrm{L}^{-1}\right)$ and cuttings type (softwood and semihardwood) on cutting survival (CS), rooting, number of roots (NOR), dry weight of roots (DWR), and root length (RL) of 'IAC-259' tea under greenhouse and commercial substrate conditions, during the summer (Jan. to Feb. 2010) and winter (June to Aug. 2010) at Piracicaba, Brazil.

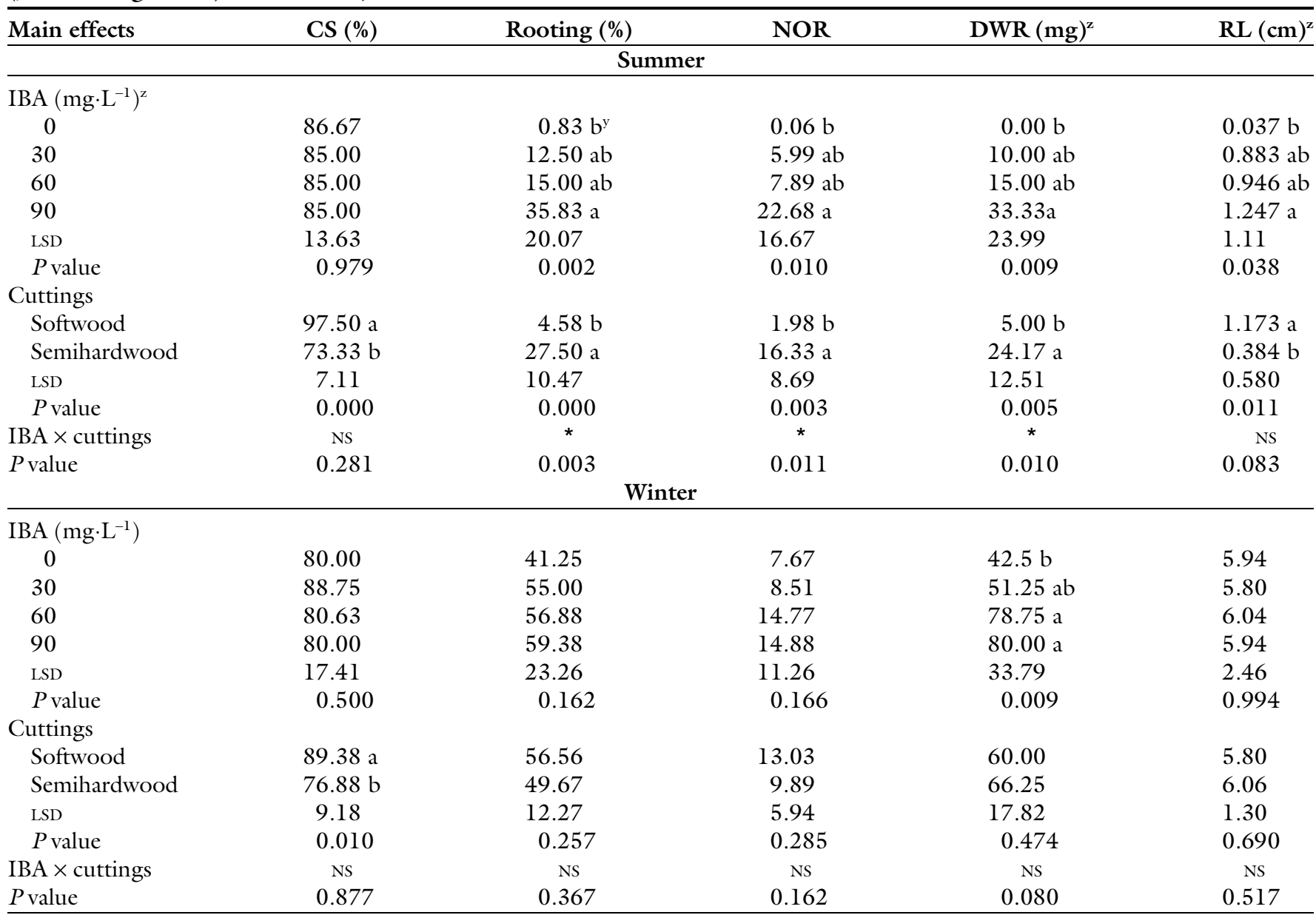

LSD $=$ least significant difference.

${ }^{2} 1 \mathrm{mg}=3.5274 \times 10^{-5} \mathrm{oz} ; 1 \mathrm{~cm}=0.3937$ inch; $1 \mathrm{mg} \cdot \mathrm{L}^{-1}=1 \mathrm{ppm}$.

${ }^{y}$ Means within columns followed by different letters differ significantly at $P \leq 0.05$ by Tukey's multiple range test.

* Significant at $P \leq 0.05$, NS $=$ not significant.

Table 3. Rooting percentage of softwood and semihardwood cuttings of 'Yabukita' tea, under greenhouse and commercial substrate conditions, treated with different concentrations of indole-3-butyric acid (IBA) during the summer (Jan. to Feb. 2010) at Piracicaba, Brazil.

\begin{tabular}{lcc}
\hline & \multicolumn{2}{c}{ Rooting (\%) } \\
\cline { 2 - 3 } IBA $\left(\mathbf{m g} \cdot \mathbf{L}^{-1}\right)^{\mathrm{z}}$ & Softwood & Semihardwood \\
\hline 0 & $16.7 \mathrm{~b} \mathrm{~A}^{\mathrm{y}}$ & $28.0 \mathrm{a} \mathrm{A}$ \\
30 & $86.7 \mathrm{a} \mathrm{A}$ & $40.0 \mathrm{a} \mathrm{B}$ \\
60 & $75.0 \mathrm{a} \mathrm{A}$ & 41.7 a B \\
90 & $75.0 \mathrm{a} \mathrm{A}$ & 55.0 a A \\
\hline
\end{tabular}

${ }^{2} 1 \mathrm{mg} \cdot \mathrm{L}^{-1}=1 \mathrm{ppm}$.

${ }^{y}$ Means followed by the different uppercase in the row and lowercase in the column differ significantly at $P \leq 0.05$ by Tukey's multiple range test.

of IBA on cuttings collected in winter might be explained by the characteristics of the plant material collected in this period, because varieties may or may not be affected by a source of exogenous auxin (Hartmann et al., 2011). The fact that rooting of IAC-259 was unaffected by the exogenous IBA on cuttings collected in the winter might be explained by different morphological, biochemical, and physiological characteristics of genetic materials.
Therefore, sources of exogenous auxin such as IBA can be used to increase the accumulation of free auxin (IAA) in the base of cuttings tissue from difficult-to-root species to induce the formation of adventitious roots (Kevers et al., 1997). These species do not have enough accumulation of IAA to initiate dedifferentiation and induction of cell division for the formation of root primordia (Ford et al., 2001). However, the response of rooting in the cuttings show variation according to the aging and the environmental effects (Lai et al., 2001) because the varieties of tea might have varietal differentiation in terms of geographical origin (Balasaravanan et al., 2003).

Types of CUTTINGS EFFECT ON ROOTING. In the summer, all rooting characteristics were not influenced by 
Table 4. Dry weight of roots (DWR), number of roots (NOR), and rooting of softwood (SC) and semihardwood (SHC) cuttings of 'IAC-259' tea, under greenhouse and commercial substrate conditions, treated with different concentrations of indole-3-butyric acid (IBA) during the summer (Jan. to Feb. 2010) at Piracicaba, Brazil.

\begin{tabular}{|c|c|c|c|c|c|c|}
\hline \multirow[b]{2}{*}{$\underline{\operatorname{IBA}\left(\mathrm{mg} \cdot \mathrm{L}^{-1}\right)^{\mathrm{z}}}$} & \multicolumn{2}{|c|}{$\operatorname{DWR}(\mathrm{mg})^{\mathrm{z}}$} & \multicolumn{2}{|c|}{ NOR } & \multicolumn{2}{|c|}{ Rooting (\%) } \\
\hline & SC & SHC & SC & SHC & SC & SHC \\
\hline 0 & $0.00 \mathrm{~b} \mathrm{~A}^{y}$ & 0.00 a A & $0.00 \mathrm{c} \mathrm{A}$ & $0.11 \mathrm{a} \mathrm{A}$ & $0.00 \mathrm{c} \mathrm{A}$ & $1.67 \mathrm{a} \mathrm{A}$ \\
\hline 60 & $13.33 \mathrm{~b} \mathrm{~A}$ & 6.67 a A & $13.85 \mathrm{~b} \mathrm{~A}$ & $1.92 \mathrm{a} B$ & $23.30 \mathrm{ab} \mathrm{A}$ & $5.00 \mathrm{a} \mathrm{A}$ \\
\hline 90 & $63.33 \mathrm{a} \mathrm{A}$ & 3.33 a B & 43.59 a A & $1.78 \mathrm{a} \mathrm{B}$ & 66.70 a A & $6.70 \mathrm{a} B$ \\
\hline
\end{tabular}

${ }^{\mathrm{z}} \mathrm{l} \mathrm{mg} \cdot \mathrm{L}^{-1}=1 \mathrm{ppm} ; \mathrm{l} \mathrm{mg}=3.5274 \times 10^{-5} \mathrm{oz}$.

'Means followed by the different uppercase in the row, and lowercase in the column, differ significantly at $P \leq 0.05$ by Tukey's multiple range test.

the types of cuttings of 'Yabukita', except for CS and PR, which were higher in softwood than semihardwood cuttings (Table 1 ). In the winter, the 'Yabukita' PR and the DWR were higher for semihardwood cuttings compared with softwood probably due to the greater quantity of carbohydrate reserves present in the semihardwood cutting. According to Fachinello et al. (2005), carbohydrates reserves can be converted into an energy source for the development of the root system.

For variety IAC-259, the CS and $\mathrm{RL}$ were higher in softwood than semihardwood cuttings in summer. However, the percent rooting, NOR, and DWR were higher for semihardwood cuttings. In winter, the type of cutting affected only CS that was $16.3 \%$ higher for softwood than semihardwood cuttings (Table 2). Variety IAC 259 had higher PR in semihardwood than softwood cuttings (Lima et al., 2013). Besides the type of cutting, the genotype and the climatic conditions also can influence the rooting development. Variety IAC 259 was developed by Agronomic Institute (IAC) located in São Paulo state, Brazil, under subtropical climatic conditions, which can get different rooting development in different seasons during the year (Hartmann et al., 2011; Maia et al., 2014).

TreatMents efFect ON CUTTINGS ROOTINGs. In summer, 'Yabukita' softwood cuttings showed increased PR with IBA application $\left(30-90 \mathrm{mg} \cdot \mathrm{L}^{-1}\right)$ as compared with the control. However, for the semihardwood cuttings, the use of this growth regulator did not affect the PR. The cuttings treated with 30 or $60 \mathrm{mg} \cdot \mathrm{L}^{-1}$ IBA showed higher PR for softwood cuttings in relation to the semihardwood (Table 3).
In softwood, cuttings of 'IAC259' propagated in summer (Table 4), the application of $90 \mathrm{mg} \cdot \mathrm{L}^{-1}$ IBA resulted in a higher DWR and NOR compared with other treatments and the control. The PR of softwood cuttings of this variety was also higher with this rate of IBA compared with $30 \mathrm{mg} \cdot \mathrm{L}^{-1}$ and the control. In contrast, semihardwood cuttings were unaffected by IBA.

According to Ford et al. (2001), the initial basal IAA concentration alone does not determine the rooting capacity; other factors are also relevant, such as the rates of production and transport of IAA in the bud, IAA conjugation metabolism, and efficiency of IAA transport to the cells that suffer dedifferentiation (Blakesley et al., 1991).

IBA did not affect the PR of semihardwood cuttings in either variety in the summer, probably due to the presence of sclereids in the tissues of the cuttings, which is common in semihardwood cuttings of difficult-to-root species. The sclereids are rich in lignin, which hinders the formation of adventitious roots (Hartmann et al., 2011). Thus, softwood cuttings are more suitable for the propagation of both varieties of this species for they have discontinuous and thin sclereids layers, which facilitate rooting (Beakbane, 1969).

Generally, results showed that IBA treatment is a way of standardizing rooting in softwood and semihardwood cuttings of tea. However, the effect of IBA depends on the type of cuttings, season of collection, and the variety of tea. Based on our experiments, we would recommend the use of exogenous IBA for rooting of cuttings collected in the summer or winter.

\section{Literature cited}

Balasaravanan, T., P.K. Pius, R. Raj Kumar, N. Muraleedharan, and A.K. Shasany. 2003. Genetic diversity among south Indian tea germplasm (Camellia sinensis, C. assamica and $C$. assamica spp. Lasiocalyx) using AFLP markers. Plant Sci. 165:365-372.

Beakbane, B. 1969. Relationships between structure and adventitious rooting. Comb. Proc. Intl. Plant Propagators Soc. 19:192-201.

Blakesley, D., G.D. Weston, and J.F. Hall. 1991. The role of endogenous auxin in root initiation. Part I: Evidence from studies on auxin application, and analysis of endogenous levels. Plant Growth Regulat. 10:341-353.

Carvalho, C.M., R.J.P. Cunera, and J.D. Rodrigues. 2005. Enraizamento de estacas semi-lenhosas de lichieira utilizando ácido indolbutírico. Rev. Bras. Frutic. 27:95-97.

da Costa, W.H., Jr., J.A. Scarpare Filho, and D.C. Bastos. 2003. Estiolamento da planta matriz e uso de ácido indolbutírico no enraizamento de estacas de goiabeiras. Rev. Bras. Frutic. 25:301-304.

Fachinello, J.C., A. Hoffmann, J.C. Nachtigal, and E. Kersten. 2005. Propagação vegetativa por estaquia, p. 69-109. In: J.C. Fachinello, A. Hoffmann, and J.C. Nachtigal (eds.). Propagação de plantas frutíferas. Embrapa, Brasília, Brazil.

Ford, Y.Y., E.C. Bonham, R.W.F. Cameron, P.S. Blake, H.L. Judd, and R.S. HarrisonMurray. 2001. Adventitious rooting: Examining the role of auxin in an easy- and a difficult-to-root plant. Plant Growth Regulat. 36:1-11.

Gomes, G.A.C., R. Paiva, J.R.F. Santana de, P.D.O. Paiva, and N.N.S. Chalfun. 2002. Propagação de espécies lenhosas. Informe Agropecuário 23:12-15.

Hartmann, H.T., D.E. Kester, F.T. Davies, Jr., and R.L. Geneve. 2011. Plant propagation principles and practices. 8th ed. Prentice Hall, Englewood Cliffs, NJ. 
Kevers, C., J.F. Hausman, O. FaivreRampant, D. Evers, and T. Gaspar. 1997. Hormonal control of adventitious rooting: Progress and questions. J. Appl. Bot. 71:71-89.

Lai, J.A., W.C. Yang, and J.Y. Hsiao. 2001. An assessment of genetic relationships in cultivated tea clones and native wild tea in Taiwan using RAPD and ISSR markers. Bot. Bull. Acad. Sin. 42:93-100.

Lima, D.J., A.C.B. Bolfarini, S.H.M.G. Silva, and W.S. Moraes. 2013. Propagação de Camellia sinensis: Efeito do genótipo, estaca, substrato, recipiente e ácido indolbutírico. Hortic. Bras. 31:74-79.
Maia, N.B., E.G. Fabri, J.R.S. Teramoto, and L.A. Saes. 2014. Chá, p. 128-130. In: A.T.E. Aguiar, C. Gonçalves, M.E.A.G.Z Paterniani, M.L.S. Tucci, and C.E.F Castro (eds.). Instruções agrícolas para as principais culturas econômicas. Instituto Agronômico, Campinas, Brazil.

Mindêllo Neto, U.R. 2005. Enraizamento de estacas de pessegueiro em função do uso de ácido indolbutírico e fertilizante orgânico. Rev. Bras. Frutic. 27:92-94.

Salisbury, F.B. and C.W. Ross. 1992. Plant physiology. 4th ed. Wadsworth, Rockville, MD.

Silva, M.D.D., M. Pasqual, F.P. Silva, J.M.M. Dias, and A.G. Araujo. 2009.
Enraizamento de estacas de baunilheira. Semina Cienc. Agrar. 30:71-80.

Wei, K., L. Wang, H. Cheng, C. Zhang, C. Ma, L. Zhang, W. Gong, and L. Wu. 2013. Identification of genes involved in indole-3-butyric acid-induced adventitious root formation in nodal cuttings of Camellia sinensis (L.) by suppression subtractive hybridization. Gene 514:9198.

Zietemann, C. and R. Roberto. 2007. Efeito de diferentes substratos e épocas de coleta no enraizamento de estacas herbáceas de goiabeira, cvs Paluma e Século XXI. Rev. Bras. Frutic. 29:3136. 